\title{
Quantum Teaching dan Pengaruhnya Terhadap Kemampuan Berargumen
}

\author{
Mei Indra Jayanti' ${ }^{1}$ Muh. Nasir ${ }^{2}$, Ardisyam Marseno ${ }^{3}$ \\ 1,2 Dosen Program Studi Pendidikan Biologi, STKIP Bima \\ 2 Mahasiswa Program Studi Pendidikan Biologi, STKIP Bima \\ Piere Tendean Kel. Mande Tel. Fax (0374) 42801, Bima84191, Indonesia. \\ Email: meiindr15@gmail.com
}

\begin{abstract}
Abstrak
Quantum teaching merupakan merupakan model pembelajaran yang dapat ditempuh untuk menciptakan kondisi pembelajaran yang aktif dan menyenangkan sehingga dapat mensukseskan proses pembelajaran untuk memperoleh hasil belajar yang maksimal. Hasil belajar bidang kognitif yang merupakan bagian dari keteramplan abad 21 salah satunya adalah kemapuan berargumen. Penelitian ini bertujuan untuk mengetahui perbedaan antara peserta didik yang diajarkan menggunakan model quantum teaching dengan peserta didik yang tidak diajarkan menggunakan model quantum teaching (non-quantum teaching). Jenis penelitian yang digunakan adalah ekperimen semu dengan desain control group pre-test-post-test. Populasi penelitian yakni seluruh peserta didik kelas XI IPA yang terdata di SMAN 1 Palibelo. Sampel dalam penelitian ini adalah peserta didik kelas XI IPA 2 dan XI IPA 3 SMAN 1 Palibelo. Data kemampuan berargumen dikumpulkan menggunakan instrumen tes pilihan ganda berpasangan yang mengadopsi pola Lawson Test of Scientifik Reasoning dengan bentuk soal pilihan ganda akibat sebab. Data kemampuan berargumen yang telah dikumpulkan lalu diolah menggunakan uji $t$ dengan bantuan SPSS 20 for windows. Hasil peneltian menunjukan bahwa terdapat perbedaan antara peserta didik yang diajarkan menggunakan model quantum teaching dengan peserta didik yang tidak diajarkan menggunakan model quantum teaching (non-quantum teaching) dengan nilai perhitungan uji $t$ yakni signifikansi $0,000<0,005$.
\end{abstract}

Kata Kunci: Quantum teachng, Kemampuan berargumen

\section{PENDAHULUAN}

Pembelajaran dirasa bermakna bila peserta didik mampu mencapai target pembelajaran yang telah dirumuskan oleh guru sesuai dengan kurikulum dan mempertimbangkan kondisi lingkungan belajar. Untuk dapat mencapai target tersebut, penciptaan suasana belajar termasuk lingkungan dan kondisi peserta didik perlu diotimalkan. Salah satu cara yang dapat ditempuh adalah dengan memilih model pembelajaran yang mampu mengkondisikan lngkungan belajar, baik itu lingkungan kelas maupun sunbek belajar itu sendiri yakni peserta didik.

Pembelajaran kuantum (Quantum teaching) merupakan pilihan model pembelajaran yang dapat ditempuh untuk menciptakan kondisi belajar yang aktif dan menyenangkan. Pembelajaran kuantum mencakup petunjuk-petunjuk spesifik untuk menciptakan lingkungan belajar yang efektif, merancang kurikulum, menyampaikan isi, dan 
memudahkan proses belajar (DePorter, dkk, lain adalah kemampuan berargumen. 2003).

\section{Quantum teaching diciptakan} berdasarkan teori-teori pendidikan seperti accelerated learning, multiple intelligences, neuro-linguistic programming, experiental learning, socratic inquiry, cooperative learning, dan elements of effective instruction. Kompleksitas teori-teori yang mendasari berdirinya quantum teaching tidak lantas membuatnya menjadi suatu model pembelajaran yang ruwet, sulit diterapkan guru atau sulit diterima peserta tidak. Tetapi quantum teaching menjadi pilihan model pembelajaran yang sederhana namun menye nangkan baik oleh guru maupun peserta didik. Hal ini terbukti dengan hasil penelitian yang pernah dilakukan oleh Jayanti (2017) bahwa pembelajaran yang menggunakan model pembelajaran kuantum mampu meningkatkan motivasi $68,89 \%$ peserta didik dbandingkan dengan pembelajaran yang tidak menggunakan model pembelajaran kuantum. Motivasi terbentuk akibat dari rasa nyaman yang dirasakan peserta didik melalui sajian gambar dan musik selama kegiatan pembelajaran (Putri, 2008). Sikap positif inilah yang memicu peningkatan kemampuan kognitif peserta didik.

Salah satu kemampuan kognitif yang merupakan bagian dari kecakapan abad 21 khususnya pada mata pelajaran sains antara
Argumentasi sangat penting digunakan dalam meyakinkan seseorang atas suatu pernyataan yang dirasa benar. Menurut Rosharyanti (2013) argumentasi sering digunakan untuk memberitahu dan membujuk orang lain untuk menguatkan sesuatu. Oleh karena itu, sebelum meyakinkan orang lain seseorang perlu terlebih dahulu mencari bukti atas anggapan yang dirasanya benar adanya.

Kemampuan berargumen adalah proses membangun suatu penjelasan logis dari topik permasalahan dan berusaha untuk meyakinkan orang lain agar meyakini kebenaran hal tersebut dengan cara memberikan alasan dengan menyajikan data atau fakta-fakta pendukung (Govier, 2010).

Emeren (1996, dalam Rosharyanti, 2013) mengidentifikasi empat karakteristik argumentasi. Pertama, argumentasi merupakan aktivitas verbal yang secara normal dibangun oleh bahasa setempat. Kedua, argumentasi adalah aktivitas sosial yang pada prinsipnya mengarahkan orang lain. Ketiga, argumentasi adalah aktivitas penalaran yang mengindikasikan beberapa pemikiran tentang suatu objek. Keempat, argumentasi terkait dengan opini tentang suatu objek yang spesifik.

Dalam rangkaian kegiatan pembelajaran yang mengarahkan orang lain untuk meyakini suatu fakta, diperlukan serangkaian proses 
menemukan kebenaran (inquiry) melalui tahapan sosial yang melibatkan aktivitas mental dan fisik dalam lingkungan yang menyenangkan. Quantum teaching mampu menyediakan kondisi-kondisi seperti ini sehingga proses pencairan fakta, pengambilan keputusan, maupun penguatan argumen dapat tercapai dalam kondisi bebas dari tekanan sehingga pembelajaran tidak lagi dirasa sebagai proses satu arah yang monoton dan menegangkan. Memperhatikan hal tersebut maka quantum teaching diyakini mampu mempengaruhi kemampuan berargumen peserta didik khususnya dalam mata pelajaran biologi.

\section{METODE}

Jenis penelitian ekperimen semu dengan desain control group pre-test-post-test. Populasi penelitian yakni seluruh peserta didik kelas XI IPA yang terdata di SMAN 1 Palibelo. Sampel dalam penelitian ini adalah peserta didik kelas XI IPA 2 dan XI IPA 3 SMAN 1 Palibelo. Kelas XI IPA 2 akan diajarkan dengan menggunakan model quantum teaching, sedangkan kelas XI IPA 3 akan diajarkan dengan pembelajaran noquantum teaching.

Instrumen yang digunakan untuk mengumpulkan data kemampuan berargumen berupa soal tes berbentuk pilihan ganda berpasangan dimana soal pertama menyatakan fakta kejadian (akibat) dan soal kedua menyatakan penyebab kejadian tersebut. Pola soal pada penelitian ini mengadopsi pola Lawson Test of Scientifik Reasoning dengan bentuk soal pilihan ganda akibat sebab. Indikator yang digunakan pada tes kemampuan berargumen terdiri dari 3 indikator, yaitu; memprediksi - mengamati menjelaskan, klasifikasi, dan menginterpretasi data.

Kriterial pemberian skor pada tes kemampuan berargumen adalah sebagai berikut:

Tabel 1. Kriteria Pemberian Skor Kemampuan Berargumen

\begin{tabular}{cll}
\hline Skor & \multicolumn{1}{c}{ Kriteria } \\
\hline 3 & $\begin{array}{l}\text { Jika peserta didik mampu menjawab } \\
\text { dengan benar item 1 dan 2 }\end{array}$ \\
\hline 2 & $\begin{array}{l}\text { Jika peserta didik hanya mampu } \\
\text { menjawab dengan benar item 1 }\end{array}$ \\
\hline 1 & $\begin{array}{l}\text { Jika peserta didik hanya mampu } \\
\text { menjawab dengan benar item 2 }\end{array}$ \\
\hline 0 & $\begin{array}{l}\text { Jika peserta didik tidak mampu } \\
\text { menjawab dengan benar item 1 dan 2 }\end{array}$ \\
\hline
\end{tabular}

Data kemampuan berargumen yang telah terkumpul lalu diolah menggukan uji t untuk menemukan perbedaan antara peserta didik yang melalui pembelajaran menggunakan model quantum teaching dengan peserta didik yang tidak diajarkan menggunakan model quantum teaching (non- quantum teaching).

Pengujian data statistik diawali dengan melakukan uji prasyarat yakni uji normalitas data hasil tes kemampuan berargumen. Setelah 
itu dilakukan uji statistik untuk melihat perbedaan hasil perlakuan. Pengujian data statistik dibantu dengan aplikasi SPSS 20 for windows.
Berdasarkan hasil uji prasyarat diketahui bahwa data berdistribusi normal (Sig. (p) $>\alpha(0,05)$ dengan nilai signifikan 0,235 . Pengujian data dinjutkan dengan uji $\mathrm{t}$ dan diperoleh hasil sebagai berikut :

\section{HASIL DAN PEMBAHASAN}

Tabel 2. Hasil Uji t Independent Samples Test

\begin{tabular}{|c|c|c|c|c|c|c|c|c|c|}
\hline & \multicolumn{2}{|c|}{$\begin{array}{l}\text { Levene's Test } \\
\text { for Equality of } \\
\text { Variances }\end{array}$} & \multicolumn{7}{|c|}{ t-test for Equality of Means } \\
\hline & \multirow[t]{2}{*}{$\mathrm{F}$} & \multirow[t]{2}{*}{ Sig. } & \multirow[t]{2}{*}{$\mathrm{t}$} & \multirow[t]{2}{*}{$\mathrm{df}$} & \multirow[t]{2}{*}{$\begin{array}{l}\text { Sig. (2- } \\
\text { tailed) }\end{array}$} & \multirow[t]{2}{*}{$\begin{array}{c}\text { Mean } \\
\text { Difference }\end{array}$} & \multirow[t]{2}{*}{$\begin{array}{l}\text { Std. Error } \\
\text { Difference }\end{array}$} & \multicolumn{2}{|c|}{$\begin{array}{l}95 \% \text { Confidence Interval } \\
\text { of the Difference }\end{array}$} \\
\hline & & & & & & & & Lower & Upper \\
\hline $\begin{array}{l}\text { Equal variances } \\
\text { assumed }\end{array}$ & 18,441 &, 000 & $-7,405$ & 49 &, 000 & $-38,487$ & 5,198 & $-48,933$ & $-28,042$ \\
\hline $\begin{array}{l}\text { Equal variances } \\
\text { not assumed }\end{array}$ & & & & 37,911 &, 000 & $-38,487$ & 5,138 & $-48,890$ & $-28,085$ \\
\hline
\end{tabular}

Tabel 2 menunjukan bahwa nilai signifikansi 0,000 lebih kecil dari 0,005 sehingga dapat diketahui bahwa terdapat perbedaan antara peserta didik yang diajarkan menggunakan model quantum teaching dengan peserta didik yang tidak diajarkan menggunakan model quantum teaching (nonquantum teaching) sehingga dapat dikatakan bahwa penerapan model quantum teaching dalam kegiatan belajar mengajar memiliki pengaruh yang signifikan terhadap kemampuan berargumen peserta didik.

Adanya pengaruh hasil perlakuan dapat diketahui melalui perbandingan hasil belajar antarkedua kelas. Dalam penerapannya, model quantum teaching memiliki kelebihan antara lain, pembelajaran menjadi lebih nyaman dan menyenangkan, peserta didik dirangsang untuk aktif mengamati, menyesuaikan antara teori dengan kenyataan, dan dapat mencoba melakukannya sendiri, pelajaran yang diberikan oleh guru mudah diterima atau dimengerti oleh peserta didik. quantum teaching lebih melibatkan peserta didik, maka saat proses pembelajaran perhatian peserta didik dapat dipusatkan kepada hal-hal yang dianggap penting oleh guru.

Berdasarkan pengamatan di lapangan saat melakukan penelitian ini, baik kondisi kelas, ekspresi peserta didik, bahkan ekspresi guru antara kelas yang menerapkan model quantum teaching dan kelas yang menerapkan pembelajaran non-quantum teaching terlihat berbeda. Perbedaan antara keduanya 
menunjukkan bahwa kelas yang menerapkan model quantum teaching tercipta kondisi kelas yang terlihat lebih bersemangat, sedangkan pada kelas yang menerapkan model pembelajaran non-quantum teaching kurang terlihat ada kegiatan pembeajaran yang istimewa.

Langkah-langkah pembelajaran dengan menggunakan model quantum teaching yang terdiri dari kegiatan tumbuhkan, alam, namai, ulangi, dan rayakan (TANDUR) mengandung sederetan makna yang tersirat maupun tersurat baik secara langsung maupun tidak langsung dapat meberikan warna baru bagi kegiatan pembelajaran di dalam kelas. Warna baru inilah yang menyebabkan suasana kelas menjadi lebih hidup.

Diamati lebih dalam pada langkah namai dari rangkaian kegiatan TANDUR, peserta didik diberi kesempatan untuk menjelaskan materi pelajaran pada teman-temannya. Adanya kegiatan ini mampu menumbuhkan rasa percaya diri peserta didik untuk mengolah informasi dan mengeluarkan argumen pribadinya dalam menanggapi permasalahan yang tertuang dalam soal LKS.

Kemampuan berargumen telah sesuai dengan teori perkembangan kognitif menurut Piaget yang membaginya dalam 2 tahap mengemukakan alasan, yaitu tahap operasional konkrit dan tahap operasional formal dengan tahap transisi diantara kedua tahap tersebut.
Seseorang yang masuk dalam kategori tahap operasional konkrit akan cenderung menggunakan logika pemikiran dengan tepat, namun akan berusaha menyelesaikan masalah di luar konsep konkrit (Moore dan Rubbo, 2011).

Setelah peserta didik membangun sendiri pengetahuan yang diperolehya berdasarkan informasi dari guru, maka tahapan selanjutnya dari langkah pembelajaran kuantum adalah demonstrasi. Pada tahapan ini informasi dan pengetahuan peserta didik dipaparkan kepada guru dan peserta didik lainnya untuk didiskusikan, sehingga dapat diklarifikasi bersama-sama. Tahapan klasifikasi merupakan kegiatan peserta didik menggunakan argumentasi untuk membenarkan pilihan mereka tentang obyek atau ide pada kategori tertentu. Sedangkan tahapan menganalisis dan menginterpretasi data merupakan kesempatan bagi untuk memutuskan data yang tersedia cukup untuk menarik kesimpulan tertentu, dan membenarkan keputusan mereka melalui argumentasi (Purwandraharja, 2013).

Kemampuan berargumen merupakan indikator hasil belajar yang dicapai dalam proses pembelajaran. Hasil belajar berkaitan dengan kemampuan dalam menyerap dan memahami bahan kajian yang diajarkan (Nasir dan Suryani 2018). Adanya pengruh pembelajaran kuantum terhadap kemamouan berargumen peserta didik dalam penelitian ini 
mampu menunjukan terserapnya materi pembelajaran dengan baik. Dampak positif lainnya yang terbentuk adalah peningkatan keaktifan akibat penciptaan kondisi lingkungan belajar yang menyenangkan. Quantum Learning tidak menghilangkan pola pembelajaran yang biasa dilakukan di kelas namun mengkondisikan suasana lingkungan dengan baik dan menyenangkan serta menambahkan beberapa langkah pengembangan peran aktif dan potensi sehingga masalah internal dan eksternal dapat dikurangi dan hasil belajar dapat ditingkatkan (Prasetyo, dkk, 2012)

Segala hal yang dilakukan dalam kerangka quantum teaching, setiap interaksi dengan, setiap rancangan kurikulum, dan setiap metode instruksional dibangun atas prinsip "Bawalah Dunia Mereka ke Dunia Kita dan Antarkan Dunia Kita ke Dunia Mereka". Inilah konsep yang menjadi asas utama dalam pembelajaran kuantum. Sebelum memulai pengajaran, guru harus mendapat izin dari untuk memimpin, menuntun, dan memudahkan perjalanan mereka menuju kesadaran dan ilmu pengetahuan yang lebih luas. Setelah mendapatkan izin tersebut, akan terbentuk sebuah ikatan antara guru dan murid yang dapat menjembatani guru dalam membawa ke dalam dunianya. $\mathrm{D}$ isaat inilah guru memfasilitasi untuk memperoleh pengetahuan. Pada akhirnya dapat membawa apa yang mereka peroleh dari dunia gurunya ke dalam dunia mereka dan menerapkannya pada situasi baru (DePorter, dkk, 2003).

\section{KESIMPULAN}

Berdasarkan hasil peneltian dan pembahasan, maka dapat disimpulkan bahwa terdapat perbedaan antara peserta didik yang diajarkan menggunakan model quantum teaching dengan peserta didik yang tidak diajarkan menggunakan model quantum teaching (non-quantum teaching) dengan nilai perhitungan uji t yakni signifikansi $0,000<$ 0,005 .

\section{DAFTAR PUSTAKA}

DePorter, B., Reardon, M., dan Nourie, S.S. (2003). Quantum Teaching. Bandung: Kaifa.

Govier, T. (2010). A Practical Study of Argument, Seventh Edition. Belmont: Wadsworth, Cengage Learning.

Jayanti, M. I. (2017). Pengaruh Penerapan Model Pembelajaran Kuantum Berbasis Masalah dengan Pendekatan Saintifik Terhadap Kemampuan Berpikir Kritis. In Seminar Nasional IKA IKIP Mataram (71). Mataram, Indonesia: Ikatan Alumni IKIP Mataram.

Moore, J.C dan Rubbo, L.J. (2011). Scientific Reasoning Abilities of Non-Science Majors in Physics-Based Course. Aps Journal. Volume 8, Issue 1.

Nasir, M., Suryani, E. (2018). Pengaruh Pembelajaran Model 5E Melalui Pendekatan Saintifik Terhadap 
Kemampuan Berargumen pada Materi Ekologi. Jurnal BioCONCETTA, Vol. 4, No. 1.

Putri, K. (2008). Implementasi Pendekatan Quantum Learning sebagai Upaya Meminimalisasi Miskonsepsi Bioteknologi di SMA Negeri 8 Surakarta.. Jurnal Penelitian Pendidikan Universitas Sebelas Maret.

Prasetyo, F. I., Santosa, S., \& Karyanto, P. (2012, June). Pengaruh Penerapan Quantum Learning Terhadap Hasil Belajar Biologi Siswa Kelas X SMA Negeri 4 Surakarta Tahun Pelajaran 2011/2012. In Prosiding Seminar Biologi (Vol. 9, No. 1).

Purwandraharja, P. (2013). Penggunaan elearning Berbasis VLE (Virtual Learning Environment) pada Materi Sistem Reproduksi Manusia untuk Meningkatkan Kemampuan Argumentasi dan Hasil belajar Kelas XI IPA SMAN 1 Jakenan Kabupaten Pati. Skripsi. IKIP PGRI Semarang.

Roshayanti, F., \& Rustaman, N. Y. (2013). Pengembangan Asesmen Argumentatif Untuk Meningkatkan Pola Wacana Argumentasi Mahasiswa Pada Konsep Fisiologi Manusia. Bioma, 2(1), 85-100. 